Table 1. Arrival and clutch initiation of Double-crested Cormorants on their nesting island in Lake Newell in April 1968 and 1969.

\begin{tabular}{l|cc|cc|cr}
\hline & \multicolumn{2}{|c|}{$\begin{array}{c}\text { Number of cormorants } \\
\text { observed }\end{array}$} & \multicolumn{2}{|c|}{$\begin{array}{c}\text { Number of clutches } \\
\text { observed }\end{array}$} & \multicolumn{2}{|c}{ Mean clutch size } \\
& 1968 & 1969 & 1968 & 1969 & 1968 & 1969 \\
\hline April 16-17 & 11 & 80 & $\ldots$ & $\ldots$ & $\ldots$ & $\ldots . .17$ \\
April 23 & 104 & 240 & 0 & 18 & $\ldots$ & 1.17 \\
April 29-30 & $\ldots$ & $\ldots$ & 5 & 69 & 1.00 & 2.29 \\
\hline
\end{tabular}

at Lake Newell arrived in numbers and started to lay earlier in 1969 than in 1968. From the comparison of data in Figure 1 and Table 1 it appears that the earlier clutch initiation in 1969 may be related to the earlier arrival of cormorants and/or the pre- ceding higher air temperatures in April that year than in 1968.

Once clutch initiation had started in 1969 a temperature drop occurring in the last week of April (Figure 1) did not appear to inhibit egg-laying to much extent (Table 1).

\title{
PARASITES FROM COMMON GOLDENEYE, GREATER SCAUP AND OLDSQUAW COLLECTED ON BOUNDARY BAY, B.C., FEBRUARY, 1970
}

\author{
by Keith Hodson and Mary Grimble, Department of Zoology,
} U.B.C., Vancouver

During the winter of 1968-69 (Nov.Feb.) approximately two dozen diving ducks were found in a weak and emaciated condition along Boundary Bay near Beach Grove, B.C. A postmortem examination of many of these ducks which subsequently died showed that they were not the victim of gunshot wounds as had been suspected. It was then decided to examine some of these ducks more closely to determine what parasites they were carrying. Two specimens each of Common Goldeneye and Oldsquaw and one Greater Scaup were examined and all parasites were preserved. Other ducks found in a similar condition during that time included Surf Scoters, Canvasbacks, Ruddy Ducks and Buffleheads.

Table 1 summarizes the identification as far as possible, the abundance, and the location of parasites found in each duck.

Because no healthy ducks were collected it is not known what levels of parasite infestations a healthy duck normally carries. It is therefore diffcult to say whether or not the overabundance of parasites was a cause of decreased health in those ducks found; however, it appeared that these ducks were carrying very heavy infestations and this probably contributed in part to the cause of their death.

Since Boundary Bay is an area of very shallow water it is an important winter feeding area for many types of waterfowl, especially divers. This, combined with the abundance of small marine life which would provide intermediate hosts for most of these parasites, would seem to provide ideal conditions for the transmission of parasites between hosts. It is suggested that ducks arriving in an area such as this during migration would be in a somewhat lowered physical condition and therefore more subject to parasitic invasions.

Many of the ducks found in emaciated conditions were kept alive as long as possible in hopes that they 
Table 1. Parasites collected from ducks on Boundary Bay, B.C., February, 1970.

\begin{tabular}{|c|c|c|c|}
\hline Host & Number & Location & Parasite \\
\hline Goldeneye No. 1 & $\begin{array}{l}100 \text { 's } \\
100 \text { 's }\end{array}$ & $\begin{array}{l}\text { gizzard } \\
\text { intestine } \\
\text { intestine }\end{array}$ & $\begin{array}{l}\text { nematode (F. Trichostrongylidae) } \\
\text { (prob. Trichostrongulus sp) } \\
\text { trematode (F. Echinostomatidae, } \\
\text { (Acanthoparyphium sp) } \\
\text { trematode (F. Strigeidae, } \\
\quad \text { (Apatemen } s p)\end{array}$ \\
\hline Goldeneye No. 2 & $\begin{array}{l}20+ \\
1 \\
2 \\
6\end{array}$ & $\begin{array}{l}\text { intestine } \\
\text { gizzard } \\
\text { intestine } \\
\text { intestine }\end{array}$ & $\begin{array}{l}\text { acanthocephalan (Filicollis } s p \text { ) } \\
\text { nematode (O. Oxyruidea) } \\
\text { tapeworm (O. Cyclophyllidea, } \\
\text { prob. Fimbiaria sp) } \\
\text { tapeworm (O. Cyclophyllidea) }\end{array}$ \\
\hline Greater Scaup & $\begin{array}{l}1 \\
1 \\
20+ \\
100 ' s \\
1\end{array}$ & $\begin{array}{l}\text { cloaca } \\
\text { proventriculus } \\
\text { gizzard } \\
\text { intestine } \\
\text { intestine }\end{array}$ & $\begin{array}{l}\text { tapeworm (O. Pseudophyllidea, } \\
\text { Schistocephalus solidus) } \\
\text { nematode, encysted, unident. } \\
\text { nematode (F. Trichostrongylidae) } \\
\text { (prob. Trichostrongulus sp.) } \\
\text { trematode (F. Echinostomatidae) } \\
\text { nematode, unident. }\end{array}$ \\
\hline Oldsquaw No. 1 & $\begin{array}{l}100 ’ s \\
100+\end{array}$ & $\begin{array}{l}\text { intestine } \\
\text { intestine }\end{array}$ & $\begin{array}{l}\text { tapeworm (F. Hymenolepididae) } \\
\text { acanthocephalan (Filicollis } s p)\end{array}$ \\
\hline Oldsquaw No. 2 & $\begin{array}{l}100 ’ s \\
50+\end{array}$ & $\begin{array}{l}\text { intestine } \\
\text { intestine }\end{array}$ & $\begin{array}{l}\text { tapeworm (F. Hymenolepididae) } \\
\text { trematode (F. Microphallidae) }\end{array}$ \\
\hline
\end{tabular}

would recover, and at this time it was noticed that they were too weak to be able to dive to any depth for any period of time. The indications therefore are that the direct cause of death was starvation because of an inability to dive for food due to the weakening effects of the parasitic loads.

As a subject of further study this duck-parasite relation seems to have an interesting potential.

\section{NORTHERN SHRIKE CAPTURES SHREW}

by Al Grass, 5666 Rumble St., Burnaby, B.C.

On April 14, 1970 while Glen R. Ryder and myself were studying Short-eared Owls, our attention was drawn to a Northern Shrike in a hawthorn bush about 40 feet from us. The bird had in its possession a small brown animal which we assumed to be a Meadow Vole (Microtus sp.). While the shrike was under observation, it

\section{LITERATURE CITED}

Yamaguti, S., 1958. Systema Helminthum, Vol. 1-5. Interscience Pub. N.Y.

Yorke, W., and P. A. Maplestone. 1962. Hafner Publ. Co. N.Y.

Nematode parasites of vertebrates. Hafner Publ. Co. N.Y.

Skijubin, K. I., N. P. Shiklobalova and R. S. Schultz. 1954. Essentials of nematodology. Acad. of Science of the USSR, Moscow.

Wardle, R. A., and J. A. McLeod. 1952. Zoology of tapeworms. Univ. Minn. Press.

Golvan, A. Y. J. 1964. An illustrated key to the genera of Acanthocephala. Paris Tr. by Ivan Pratt, Dept. of Zool. Oregon State University.

proceeded to impale the animal on a hawthorn spine. We decided to approach more closely and to our surprise the shrike allowed us to come within 10 feet of it and seemed almost defiant. Once the bird flew we examined the small mammal more closely. It proved to be a Cinereus or Masked Shrew (Sorex cinereus). According to the literature, it is apparently uncommon for shrikes to feed on shrews.

The incident took place in the municipality of Delta, some 30 miles from Vancouver, B.C. 